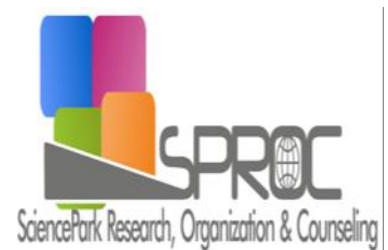


$\longrightarrow$

( 


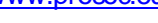

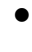

$\bullet$

$\bullet$

$\bullet$

$\bullet$

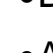

$\bullet$

- 


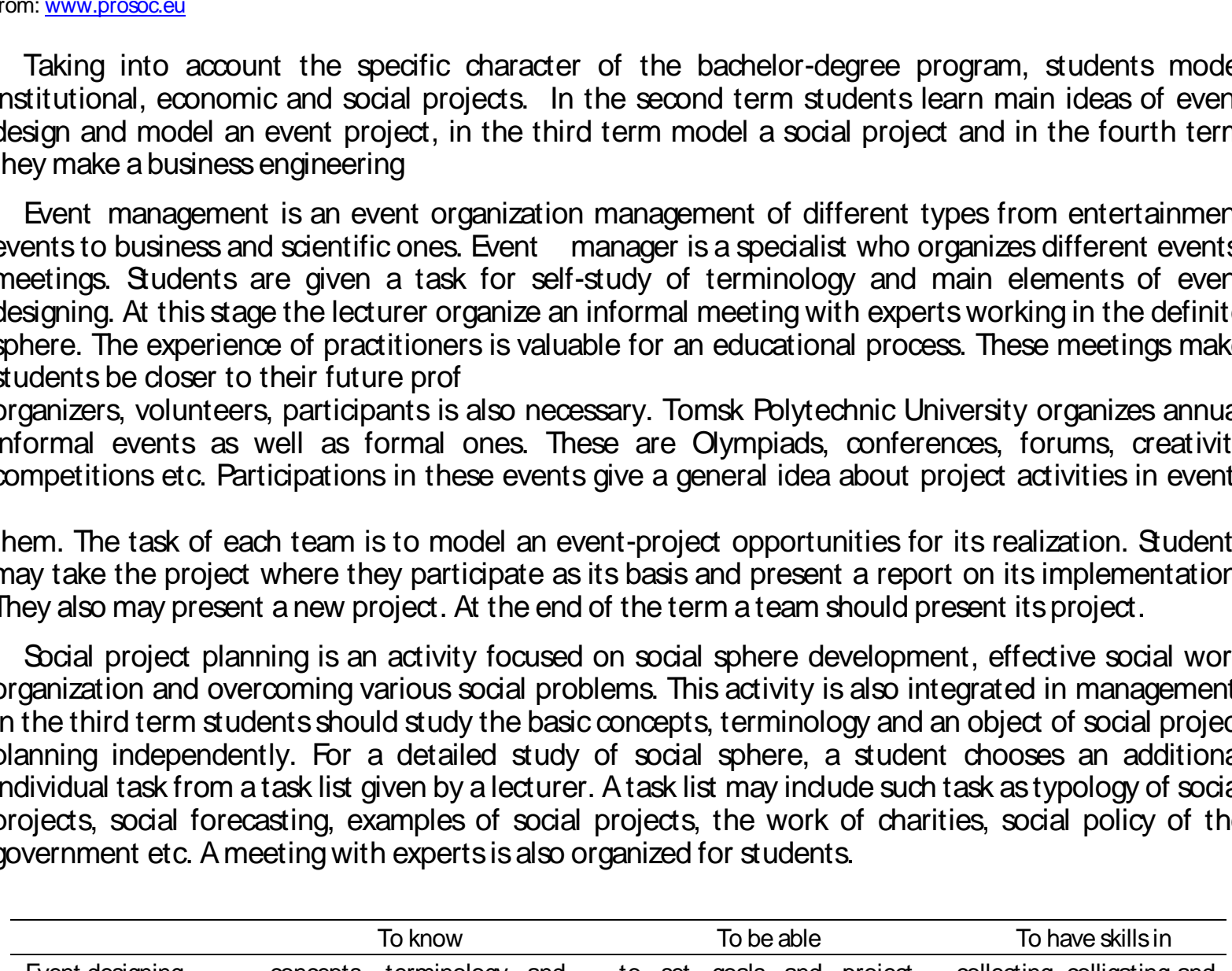


\section{$\bullet$ $\bullet$ $\bullet$}




$$
\bullet
$$

$$
\text { - }
$$

$\bullet$

$\bullet$

$\bullet$ 

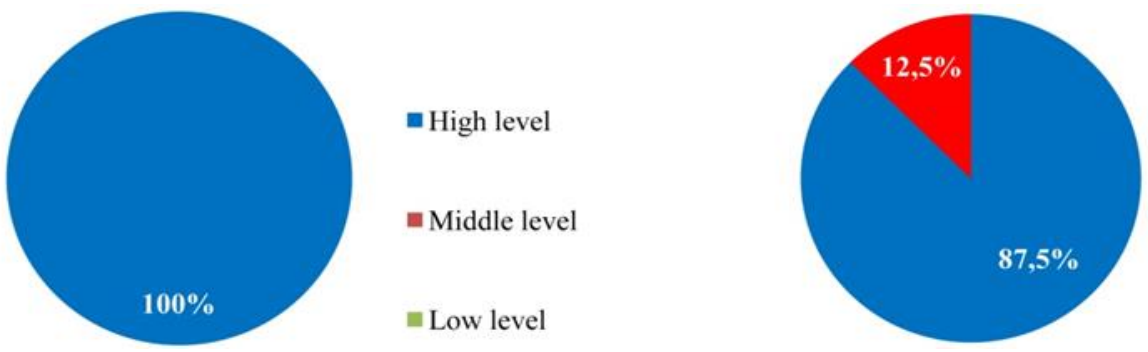

- The connection is clear

- The connection is partially

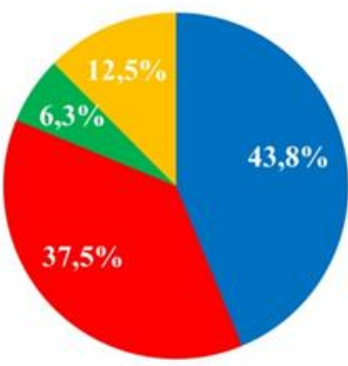

- Excellent

- Very good

a Good

Fair

= Poor

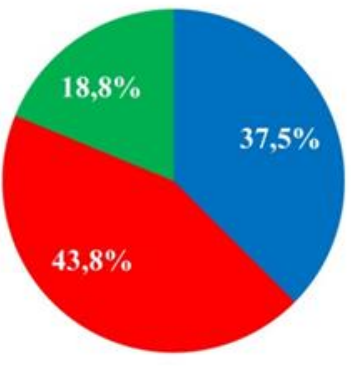

- Excellent

- Very good

= Good

wair

- Poor 
$\longrightarrow$

( 